\title{
The Development of Case Assignment in Forensic Accounting Education
}

\author{
Masako Saito ${ }^{1,2}$, Sekar Mayangsari ${ }^{1,2, *}$ \\ ${ }^{1}$ Kansai University, ${ }^{2}$ Universitas Trisakti \\ ${ }^{1}$ Osaka, ${ }^{2}$ Jakarta, ${ }^{1}$ Japan, ${ }^{2}$ Indonesia \\ *sekar_mayangsari@trisakti.ac.id
}

\begin{abstract}
This paper studies for the develop of good materials and tools in forensic accounting education based on the Japanese cases. We use undergraduate students as respondents. In this paper, we suggested the case assignment that was developed by the past fraud cases, as the proposed educational material and examined the effect of respondents. At this time, the examination was enforced for the respondents from the practitioners and accounting students in Indonesia, whose economy has been developing rapidly. We found the interesting results as follows; (1) there is the difference of decision-making between case situations to manipulate financial numbers. (2) practitioners tend to more sympathize with a company and a fraudster who manipulate the financial number than students. In the other hand, (3) students tend to feel more pressured to the authority or higher position in a company.
\end{abstract}

Keywords-forensic accounting education, corporate governance, students, practitioners

\section{INTRODUCTION}

We witnessed to see big fraud cases in worldwide. Even Japan, there are recent scandals for global fraud cases, such as Toshiba, Nissan, and Olympus. The financial statements frauds caused a big shock in that country as well as in the entire world. It showed us no matter how big and famous they are, they couldn't prevent from the frauds. Although it is not easy to understand each case, at least we can understand that all of their governance system was not worked effectively. Wherever firm and organization do business activities, they have the risk to face on any frauds. We need to get know well to have the possibility to meet the fraud or involve partly in such activities. We shouldn't be misled by the scale or reputation of the company or organization. It might be very difficult for us to discover them, because they have been more and more skilful for a clever trick. In recent years among people who involve in such a financial statement fraud, there are some professionals with sophisticated accounting or financial knowledge like $\mathrm{CPA}, \mathrm{CFO}$, or someone at other higher professional status. That result in the increase of loss of fraudulent activities. Indeed, the 2018 ACFE (the Association of Certified Fraud Examiners) report shows that financial statement fraud causes a median loss of $\$ 0.8$ million among the total of 2,690 fraud cases studied worldwide [1]. In this situation, investors must be more careful to invest in global market and need the more trustful for financial reporting. Educators can play a role to foster people to educate higher and wider-spread knowledge and skill to combat these frauds. When we teach students, the past fraud cases are effective to tell them how to recognize, understand, and prevent these fraudulent activities.

Therefore, forensic accounting education need always 'new' or 'well-shaped' materials for students to get motivated for learning. We suppose that good educational material could explain the definition of the fraud and the impact on global market. In accounting education, how should we contribute to developing effective corporate governance to prevent frauds? The use of historical fraud scandals would be the one of good ways to instruct students toward anti-frauds. In addition, it would be expected that younger generation would understand what the significance of making decision followed the law and regulation is. In the Asian countries, the economy of Indonesia keeps developing. Because of the economic growth, it faces to the anti-fraud control. In 2018, Indonesia was the 3rd worst in the Asian pacific countries at the ranking of fraudulent cases. As one of good solutions, we need to serve good forensic accounting education. Better educational materials or tools for students would foster younger generation with construct their business morality. It could realize the reliable and sustainable society. Forensic accounting is an important tool to combat fraud. Current initiatives in accounting education emphasize continuous lifelong learning and outcome-based assessment, while focusing on the importance of accounting instruction and teaching students how to learn. Therefore, many of accounting education's efforts aim to instruct students on what to learn from those scandals. An emphasis in forensic accounting allows us to consider and study fraudulent activities to better detect and control fraud in the future. This paper studies how to examine the effect using assignments proposed through the analysis of the Japanese firms' cases and then develop effective educational material to anti-fraud.

As everyone knows, most of Japanese firms are well known in global countries. However, in past recent years, among them, several firms have caused a scandal for financial statement fraud. For example, the audit committee of Nissan Motor Corporation disclosed that former Chairman and Representative Director Carlos Ghosn and former 
Representative Director Greg Kelly concealed more than \$327 million in payments to themselves and other executives. The amount is the sum of $\$ 187$ million in nondisclosed compensation and $\$ 140$ million in improper expenditures [2]. According to the announcement of the Securities and Exchange Commission (SEC), Nissan agreed $\$ 15$ million penalty to the SEC to charge the ex-Nissan executive with fraud. We can tell the other story for the Olympus case. The fraud case of the manufacturing firm of precision machineries and instruments has got famous over the world because of not typical pattern as if it was a kind of mystery. The former CEO, Michael Christopher Woodford asked PricewaterhouseCoopers (PwC) to investigate and noticed the facts of the unusual M\&A transactions. He accused the Chairman Kikukawa to take responsibilities, however, the board decided to fire Woodford. Surprisingly, the series of their fraudulent activities had been over 20 years and then several highly educated financial advisors involved in the Olympus's top executives. The financial specialists had long-term experiences working for Nomura Securities, the biggest security company in Japan and Olympus's main broker. Then, the fraud case of Toshiba Corp. has been revealed in 2015. The net income of the annual ending March 2014 has been over manipulated to the 1.2 billion yen, although it was the net loss of 378 million yen. The announcement of the Independent Investigation Committee showed that the cumulative delegation of income before taxes from FY 2008 to the third quarter of FY 2014 reached to minus 1.5 billion yen [3]. At least, several ex-President involved in the manipulation of income. It means that the executive committee as well as the audit firm couldn't play a significant role for the corporate governance. And on September 15, 2015, due to the internal management system of the company the stock of "Toshiba" was put under management rebuilding designated by the Tokyo Stock Exchange.

\section{LITERATURE REVIEW}

There were several factors that force somebody do fraud. The Fraud Triangle developed three factors of fraud: opportunity, pressure and rationalization [4]. Another study found that based on SAS no.99, we could detect and predict financial statement fraud [5]. The reason why as we learned the Olympus case, a kind of solidarities prevent the employees from considering the fraudulent activity as the bad thing. Some of them cooperated and hided the illegal activities. So, if people face to such as fraudulent activities, how and what should they consider? It would be much constructive for us to the deterrence of accounting frauds toward the reliable society, developing more effective materials in forensic accounting. As prior suggested that there were many empirical evidence shows the differentiation between the perception of students and practitioners toward fraud [6-8]. This study need to test the alignment between those perceptions because in the near future the students become practitioners, and in past, the practitioners were students, Prior study found that both of respondents have common characteristics when make a decision especially if correlated with fraud $[8,9]$. Through the consideration above, we suppose two hypotheses as follows;
- H1: There are some differences of perceptions about manipulated financial number between practitioners and students

- H2: There are some difference of feeling to disagree for manipulation of the financial numbers between practitioners and students.

\section{METHODS}

Firstly, we examine how the effect of the proposed educational assignment is. We got 79 respondents of 36 practitioners and 43 undergraduate students in Indonesia. Practitioners who belong to BCA (Bank Central Asia, Indonesia), experience the knowledge and activities of the financial statements to a certain degree. In the meanwhile, accounting students of Universitas Trisakti, Jakarta already learned the basis of financial statements and the vocabularies. In this situation, we consider as them to know that the manipulation of financial numbers would be contrary to the law in any reasons. In addition, it supposed any difference between BCA staffs and undergraduate accounting students.

\section{RESULTS AND DISCUSSION}

\section{A. Results}

In this study, we got the data to give BCA practitioners and accounting students of Trisakti University to answer the assignment. The Assignment (Appendix shown) consists of total of five case questionnaires. Case Question (CQ) 1 is how respondents should do their own action, if they discover the superior's fraud. Respondents have to choose one appropriate action from $A$ to $G$ which they should do. Answer $A$ (put score 1 ) is the most positive action to accuse my boss. $G$ (put score 7 ) is the most negative action to do nothing with silence. Exhibit 1 shows the cross tabulation of CQ 1 and CQ 2. As for CQ 1 data shown, nobody didn't choose $F$ and $G$. Case Question (CQ) 2 is what the extent of respondents' morality for fraudulent activity is. If a person considers strongly any accounting frauds aren't justice, he or she would choose 'strongly disagree' (put score 1). It found nobody didn't choose 'strongly agree' (put score 5).

As some of the Exhibits show, the result of $\mathrm{T}$ test is significantly supported $(\mathrm{p}<.000)$. It means that hypothesis 1 and 2 are statistically examined. Exhibit 2 shows the mean of respondents categorized by practitioners and students. Visually, the mean in CQ 1 and 2 of practitioners is almost close, compared with the mean of students. CQ 3-1 to 3-3 differ with the reason why a person tries to manipulate the financial number is. We prepared three situations when to discover fraudulent activities; CQ 3-1 for company performance, CQ 32 for family problem, and CQ 3-3 for boss pressure. Our motivation is to examine that decision making or action to antifraud could change by the difference cases, CQ 3-1, 3-2 and 33. Interestingly, there are some differences between practitioners and students, as well as between CQs. First, all of the mean of CQ 3- 1 to 3-3 of practitioners is higher than 
students. Among them, the biggest difference is the mean of CQ 3-2 which are supposed as a kind of family problem. It means that practitioners tend to have a kind of sympathy to the co-worker stronger than students. Some people might consider because family problem like illness is the inevitable matter, then the manipulation of financial statements for that is acceptable. However, any other reasons, we know that the financial statements fraud including the manipulation is illegal and not should not be accepted. On the other hand, the mean of students is basically lower than practitioners. The biggest mean of students is CQ 3-1 for company performance. Students feeling or decision-making sometimes depend on the better performance, which might be motivated to get higher score in their class evaluation.

TABLE I. FREQUENCY OF CROSS TABUlation

\begin{tabular}{|c|c|c|c|c|c|}
\hline \multicolumn{6}{|c|}{ Frequency } \\
\hline \multicolumn{5}{|c|}{ Case Question 1} & \multirow{2}{*}{ Total } \\
\hline $\bar{A}$ & $B$ & $C$ & $D$ & $E$ & \\
\hline 2 & 8 & 16 & 4 & 6 & 36 \\
\hline 5 & 2 & 15 & 7 & 14 & 43 \\
\hline 7 & 10 & 31 & 11 & 20 & 79 \\
\hline \multicolumn{6}{|c|}{ Frequency } \\
\hline \multicolumn{5}{|c|}{ Case question 2} & \multirow[t]{2}{*}{ Total } \\
\hline \multicolumn{2}{|c|}{$\begin{array}{l}\text { Strongly } \\
\text { disagree }\end{array}$} & $\begin{array}{c}\text { Disagree } \\
2\end{array}$ & $\begin{array}{c}\text { No Opinion } \\
3\end{array}$ & $\begin{array}{c}\text { Agree } \\
4\end{array}$ & \\
\hline \multicolumn{2}{|l|}{11} & 17 & 8 & 0 & 36 \\
\hline \multicolumn{2}{|l|}{14} & 23 & 1 & $\frac{5}{5}$ & 43 \\
\hline \multicolumn{2}{|l|}{25} & 40 & 9 & 5 & 79 \\
\hline
\end{tabular}

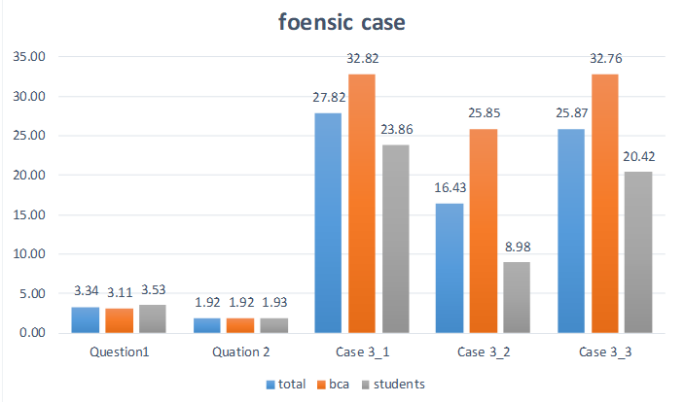

Fig. 1. Comparative mean in BCA and students.

TABLE II. STATISTICS AND RESUlt OF T TEST

\begin{tabular}{|l|c|l|l|l|l|l|}
\hline \multicolumn{2}{|c|}{ Statistics } \\
\hline & $\begin{array}{c}\text { d of } \\
\text { freedom }\end{array}$ & Mean & $\begin{array}{c}\text { Standard } \\
\text { Deviation }\end{array}$ & \multicolumn{3}{|c|}{ Mean of Standard Error } \\
\hline affiliation & 79 & 1.54 & .501 & .0560 & \\
\hline 1tugas & 80 & 3.3418 & 1.231 & .1376 & \\
\hline 2wajar & 80 & 1.9241 & .833 & .0920 & \\
\hline 3_kasus & 78 & 27.8182 & 23.129 & 2.6188 \\
\hline 3_2kasus & 78 & 16.4286 & 19.266 & 2.1815 \\
\hline 3_3kasus & 78 & 25.8701 & 20.735 & 2.3478 \\
\hline
\end{tabular}

\section{CONCLUSION}

Several financial scandals in Japan showed that there were any kinds of pressure from the superior to employees, the high level of solidarity in the corporate culture, and the weaker status of the Japanese accounting firms. All of them was very important, when trying to explain how the fraud happened. Such circumstances might seem partly specific to Japan, but partly common characteristics in any other Asian countries where have similar culture. The more globalized firms become, the more difficult auditing them becomes, yet the more significant auditing becomes. In addition, the more globalized firms become, the more critical it becomes to consider the local corporate cultures when looking for frauds. One of the important messages for those planning programs in forensic accounting education is the need to prepare students to consciously and bravely confront fraud. In this paper, we learned that it is sometimes difficult to find and confront fraud. The Olympus, Toshiba, and Nissan cases as Asian representing companies show that we should try to educate students to consider carefully and to be strong when facing frauds. Then, we need to foster sceptical accounting professionals to maintain the corporate governance everywhere in the world.

First, through the analysis of the case studies, we got some implications. A series of continued fraudulent activities based on three Japanese fraud cases emphasizes a kind of solidarity between employees and executives in the same organization and the barrier to conceal frauds. Furthermore, people feel the pressure or threat from the authority like boss, superior, and executive. We consider that such environmental situation might make people not tend to positively do action to combat fraud. However, those forensic cases give us the significance of our objective attitude. No matter what anyone faces on the difficult situation, the manipulation of financial numbers is not acceptable. Simply, that is the crime. Second, the statistical examination showed the interesting results as follows; (1) there is the difference of decision-making between case situations to manipulate financial numbers. (2) practitioners tend to more sympathize with a company and a fraudster who manipulate the financial number than students. In the other hand, (3) students tend to feel more pressured to the authority or higher position in a company. The statistical difference is a variety of decision-making between practitioners and accounting students in the supposed fraud cases. This implication shows the needs of distinguished case study tools. It means that we try to develop the educational tools fitted for practitioners only and student only. Anti-fraud control would be supported by the constant efforts by educator in the world. This study has limitations in the number and scope of sample. We will try to make the higher explanation by getting more respondents in Asian countries through developing these case assignments more effective.

\section{REFERENCES}

[1] B. Dorris and F. Examiners, "Report to the nations: Global study on occupational fraud and abuse," Assoc Certif Fraud Exam [Online]. Retrieved from: https://www.acfe.com/report-to-the-nations/2020/, 2020.

[2] M. Horie, Nissan suing ex-chair Carlos Ghosn for \$91 million. Fortune. 
[3] S. Hass, P. Burnaby and M. Nakashima, "Toshiba Corporation-How Could So Much Be So Wrong?" J Forensic Investig Account., vol. 10, no. 2, pp. 225-249, 2018.

[4] D. Cressey, "Other's People Money: A Study in The Social Psychology of Embezzlemet," Am J Sociol., 1953.

[5] C.J. Skousen, K.R. Smith and C.J. Wright, "Detecting and predicting financial statement fraud: The effectiveness of the fraud triangle and SAS No. 99," Corporate governance and firm performance. Emerald Group Publishing Limited, 2009.

[6] Z. Rezaee and E.J. Burton, "Forensic accounting education: Insights from academicians and certified fraud examiner practitioners," Manag Audit J., vol. 12, no. 9, pp. 479-489, 1997.
[7] C.K. Tunca and D. Crowther, "The Necessity of Fraud Education for Accounting Students: A Research Study From Turkey," Soc Responsib J., vol. 2, no. 3-4, pp. 321-327, 2006.

[8] N. Sasongko and M.N. Hasyim and D. Fernandez, "Analysis of behavioral factors that cause student academic fraud," J Soc Sci Res., vol. 5, no. 3, pp. 830-837, 2019.

[9] J.M. Bartunek and S.L. Rynes, "Academics and Practitioners Are Alike and Unlike: The Paradoxes of Academic - Practitioner Relationships," J Manage., vol. 40, no. 5, pp. 1181-1201, 2014. 